\title{
INFLUENCE OF WORK ENVIRONMENT ON EMPLOYEES PERFORMANCE IN NIGERIA
}

\author{
Dr. Cross Ogohi Daniel \\ Department Of Public Administration \& Banking and Finance \\ Nile University Of Nigeria, Abuja \\ Danielcross@Nileuniversity.Edu.Ng , Ph: +2347086253343
}

In view of the perceive unsupportive, unsafe and unhealthy work environment and the continuous dwindling employee's performance in the service-oriented organization despite efforts by government to ensure improve employee's performance at the Ministry of Works and Infrastructure at Bayelsa State. The specific objectives are to establish how physical workplace environment, workplace reward, work-life balance and management-leadership style on the performance of employees at the Ministry. Thus, using a descriptive survey research design, a sample size of 142 employees were drawn from the total population of 220 staffs of the Bayelsa State Ministry of Works and Infrastructure using Taro Yamene sampling technique. A sample random and proportionate sampling technique was employed to determine the sample size for the study. For the purpose of data analysis, a close ended (called a 5-point likert scale) questionnaire was used to collect data from the sampled employees. Before administration validity check was performed on the questionnaire and after administration, reliability check was conducted to ensure credibility of responses. First, it was discovered that the physical workplace environment factors have significantly effect on employee's commitment to work. Secondly, this study discovered that work reward has significant impact on employees' productivity. Also, this study found-out that work-life balancing has significant influence on employees' work efficiently. Therefore, it was recommend, that management of the Ministry of Works and Infrastructure Bayelsa State should build a supportive work-environment to improve employees' performance.

KEYWORDS:Work Environment, Leadership Style, Empirical and Employee Performance

\section{INTRODUCTION}

Employees' performance, though a multidimensional construct, refers to a task accomplishment degree that constitutes their job performance. Similarly, Rizwan, et al. (2016) viewed employees' performance in terms of their work quantity, quality and efficiency. It is also associated with productivity which implies output quantity, output quality, output timeliness, job presence, work morale, work efficiency and effectiveness (Bambale et al. (2016). The effectiveness of the employees in achieving expected results has a far-reaching effect on organizational functioning. This is why Boarman and Motowidlo (2017) conceived employees' performance as their effectiveness to perform their tasks that contributes to organizational core aims through the conduciveness of their operating environment. As Samson, et al. (2015) rightly noted the imperativeness of employees' performance for organizational existence cannot be overemphasized. Conspicuously, numerous factors shapes employees' performance, unarguably, workplace influence is a 
noticeable factor. This is why Mathew and Khan (2015 aver that employee performance refers to the summation of achieving, ability and task perception.

However, Armstrong (2009) argues that motivation, ability and opportunity to participate are notable factors of employee's performance. In a nutshell, performance is a function of ability and motivation. However, these two factors (functional anility and motivation) are also themselves dependent on quite some deterministic factors one of which is the workplace environment.

Nowadays, workplace is multifaceted and highly dynamic, thus, the orthodox employeremployer relation has been turned upside-down; implying that employees are now in a new era with unlimited job opportunities. However, in spite the fact that an effective workplace is a condition for performance improvement, still organizational workplace present absence of safety, health and comfort challenges. Employees in an unsupportive workplace invariably results to occupational health diseases leading to low performance.

Thus, organizations in the 21 st cannot survive (in the long-run) without careful workplace consideration. Although organizations in Nigeria, like their counterparts across globe, operate within an environment, however, despite the scholastic renaissance especially among contemporary scholars on the instrumentality, topicality and primacy of workplace as a decider of employees' performance, studies devoted to this area in Nigeria are unexplainably and unmistakably scanty, thus leading the researcher in quandary on whether workplace environment affects employees' performance in Nigeria especially at the Ministry of Works and Infrastructure Bayelsa State. Preponderance of studies are devoted to organizations in developed nations(such as United Kingdom and United State of America) who are perceivably more sensitive to workplace situation and developing nations like Nigeria.

\section{STATEMENT OF THE PROBLEM}

Another undeserving characteristic of workplace environment at the Ministry is the Management/leadership that has become worrisome due to the frequent changes as most appointments are politically motivated not meritoriously inclined; leading to unstable management/leadership styles (e.g. autocratic, democratic, liaises faire) that produces different situations, hence administrative lapses. In lieu of individuals with effective management/leadership traits, the Ministry has continued to record the appointment of leaders with ineffective leadership style. Considering the indisputable fact that leadership affects a wide array of work behaviours, including employees motivation, self-efficacy, creativity, and coping with stress in addition to predicting crucial work-related outcomes such as task performance, however, the employees' attitude to work under the management/leadership styles has gained less research attention.

\section{OBJECTIVES OF THE STUDY}

The main objective of the study is to examine the impact of work environment on the performance of employees at Ministry of Work and Infrastructure Bayelsa State. Other specific objectives of the study are:

i. To evaluate the degree at which work-life balancing influence employees' work efficiency in Ministry of Work and Infrastructure Bayelsa State.

ii. To examine how management/leadership style affects employees' work-attitude in Ministry of Works and Infrastructure Bayelsa State.

\section{RESEARCH QUESTIONS}

The study is guided by the following research questions:

i. To what degree does work life balancing influence employees' work efficiency in Ministry of Works and Infrastructure Bayelsa State. 
ii. How does management/leadership style affect employees' work-attitude in Ministry of Works and Infrastructure BayelsaState?

\section{RESEARCH HYPOTHESES}

The study is guided by the following null hypotheses

$\mathbf{H}_{1}$ : There is no significant influence of work-life balancing on employees' work efficiency in Ministry of Works and Infrastructure Bayelsa State.

$\mathbf{H}_{2}$ : There is no significant relationship between management/leadership style and employees' work-attitude in Ministry of Works and Infrastructure Bayelsa State.

\section{RESEARCH METHOD}

This research therefore covers one selected federal ministry in Bayelsa State, ministry of works and infrastructure. Secondary data were obtained through books, journals, and internet. Empirical works of other scholars were consulted. A simple size of 142 was obtained from the population of 220 at 5\% error tolerance and 95\% degree of freedom using Yamane's statistical formula $142(100 \%)$ of the questionnaires distributed $130(91.5 \%)$ were returned and 12(8.5\%) were not returned. The questionnaire was designed in Likert scale format. The researchers conducted a pre-test on the questionnaire to ensure the validity of the instrument. Regression analysis was used to test the hypotheses.

\section{LITERATURE REVIEW}

\section{Concept of Work Environment}

Employees in conducive working environment and condition feels safer and display better health status on the job which consequently enhances employees' comfort and motivation which increases their productivity level. Easily usable tools and equipment, conducive working methods, well-ventilated, good lightening conditions and air-conditioned environment are main impetuses for employees to be spurred to put in their best. Supportive workplace conditions and environment give a sound workplace that limits the propensity of employees to create one sickness or the other. Sound ergonomically arrangements in workplace guarantee and continue the effective wellbeing states of employees. Jain and Kaur (2014) express that workplace can involve the social connection at working environment and furthermore sustain the relationship among partners, supervisor and the association. It depicts the neighbouring situation in which employees are working. A favourable workplace may give demonstrate tasteful to labourers. A fulfilled, upbeat and persevering employee is the greatest resource of any firm. Compelling outcomes and efficiency for any firm is subject to the dimension of fulfilment of employees and workplace is a standout amongst the most imperative variables which impact the fulfilment and inspiration dimension of employees. Knudsen, Ducharme, Roman, Lawson, Rupert and Morgan's investigation (as referred to in Cunningham, Small and Daire, 2014) express that almost nothing is known about each setting's ideal individual environment coordinate, which increases burnout and turner in the field settings.

Employees in numerous firms are experiencing work and work-related issues identified with work environment and physical components. Funminiyo (2018) submitted that employee disengagement is expanding and it has turned out to be vital to make working environment that condition, has perceived as an imperative factor for estimating their productivity (Duru\&Shimawua, 2017) Assaf and Alswalha (2013) reported that in the present dynamic and aggressive business arena, a sound work environment bodes well. This implies that supervisors should not simply concentrate on the employees' compensation parcel with the supposition that it is proportionate to their performance. Firms regarded to have a favourable work environment usually have a competitive edge over others. Comprehending the basic 
significance of working environments in a firm is to perceive that the human factor and the firm are the same. Unstable environments furnish workers with both opportunity and heap of difficulties but through a fair working environment, a firm streamlines productivity and enhancing the organization's goodwill as a working environment; anticipating a cutting-edge corporate element, which thus can enable one to attract talented employees. Building configuration influence the manner in which individuals behave, with designers making conditions that can impede, demoralize, guide, support or upgrade clients' (AffumOsei\&Azunu, 2015). Most foundations are starting to rethink how their workplace is structured and what offices they offer to staff that has extensive impact on their overall performance. An empowering workplace remains the driver or an enabler to enhancing performance. Work environment is an idea that has extensive impact on their overall performance. Work environment is an idea that has been operationalized by dissecting the degree to which employees see their immediate surrounding' as satisfying their characteristic, outward and social needs and their reasons of remaining with the organization (Iman\&Shhafique, 2014). The greatest objectives of every commercial organization are to build and boost their performance and generating increase profits.

\section{Workplace EnvironmentalFactors}

The workplace environment involves different variables that are basic determinants of worker execution (Lamber, 2001). The components may decidedly or adversely add to accomplishing greatest worker performance.

\section{i. Work Life Balance}

Work life balance alludes to one of the accompanying organizational help for war care, adaptable work alternatives and family or individual leave (Estse\& Michael, 2005). Work life balance business researches are worried about giving degree to employees; to balance what they do at work with the duties and interests they have outside work (Armstrong, 2006). By so doing, they accommodate the contending cases of work and home by their own needs just as those of managers. Work life balance approaches can bring don nonappearance and help handle the low spirit and high degrees of stress that can prompt underperformance since the representatives become weary of juggling work and life obligations. Numerous specialists have conceded to critical job of work life balance as it is connected with representatives' mental prosperity and by and large feeling of agreement in life (Clark, 2010).

\section{ii. Physical Workplace Environmental factors}

Ismail et al. (2010) posits that physical workplace conditions impact the workers' capacities and it will decide the prosperity of organizations. They noted that the physical work environment incorporates the inside and outer office design, temperature, safe places including the work setting or plan. The physical workplace environment factors additionally incorporate lighting (both fake and regular), clamor, furniture and spatial formats in workplaces (Vischer, 2007). The physical workplace environment incorporates comfort level, ventilation and warming, lighting. These highlights help on practical and tasteful side, the stylistic theme and structure of the workplace environment that at last help enhance the representatives' involvement and require better execution.

\section{iii. Work Life Balance}

Work life balance alludes to one of the accompanying organizational help for war care, adaptable work alternatives and family or individual leave (Estse\& Michael, 2005). Work life balance business researches are worried about giving degree to employees; to balance what they do at work with the duties and interests they have outside work (Armstrong, 2006). By 
so doing, they accommodate the contending cases of work and home by their own needs just as those of managers. Work life balance approaches can bring don nonappearance and help handle the low spirit and high degrees of stress that can prompt underperformance since the representatives become weary of juggling work and life obligations. Numerous specialists have conceded to critical job of work life balance as it is connected with representatives' mental prosperity and by and large feeling of agreement in life (Clark, 2010).

\section{iv. Management/Leadership Style}

Leaders greatly affect their subordinate improvement. Managers employ a specific leadership style, which draws out the best out of the employees. Thus, the employees' morale will influence their performance decidedly or adversely. Story (2014) states the transformational leadership style which is made out of thoughts, impact, moving inspiration, scholarly incitement and individualized thoughts is a standout amongst the best leadership styles. These segments of transformational leadership give elite and effect, high on worker's fulfilment. There is additionally a down to business arranged leadership, which stresses on leadership of fairness between the pioneers and subordinates. All individuals from the organization have equivalent and same law, date and point of view and the job of the pioneer is encouraging the arrangement of the organization (Duckett and Macfarlane, 2013). This sort of leadership is best. Fruitful leadership is in this manner exceptionally essential for the organizational viability and worker performance. Leadership style influences a scope of components, for example, work fulfilment, execution, turnover goal thus adds to organizational achievement. Administrators need in this manner to receive suitable leadership conduct so as to enhance employees' performance.

\section{Employee Performance}

Miebi (2014) stated that employees' performance is depending on the willingness and also the openness of the employees itself on doing their job. He also stated that by having this willingness and openness of the employees in doing their job, it could increase the employees' productivity which also leads to the performance. Kunze et al. (2013) also explained that to have a standard performance, employers have to get the employee task to be done on track as to achieve the organization goal or target. By having the work or job done on the track, employers could be able to monitor their employees and help them to improve their performance. Furthermore, a reward system should be implemented based on the performance of the employees. This is to motivate the employees in order to perform more on their task. There are several factors that being described by Nwinami (2014) towards the success of the employees' performance. The factors are such as physical work environment, equipment, meaningful work, performance expectation, and feedback on performance, reward for good or bad system, standard operating procedures, knowledge, skills and attitudes. Mmakwe and Ojiabo (2018) defined performance that relies on internal motivation, but presence of internal factor such as necessary skills, intellectual capacity and resources to do the job clearly have an impact. As a consequence, employers are supposed to provide appropriate working condition in order to make sure the performance of employees meet the required standards. This study conceives employees' performance to hinge on employees' commitment, productivity, work efficiency and attitude to work. 


\section{TEST OF HYPOTHESES}

H0 $_{1}$ : There is no significant influence of work-life balancing on employees' work efficiency in Ministry of Works and Infrastructure Bayelsa State.

Table 1 Model Summary

\begin{tabular}{|c|c|c|c|c|c|c|c|c|c|}
\hline \multirow[t]{2}{*}{ Model } & \multirow[t]{2}{*}{$\mathrm{R}$} & \multirow{2}{*}{$\begin{array}{c}\mathrm{R} \\
\text { Square }\end{array}$} & \multirow{2}{*}{$\begin{array}{c}\text { Adjusted } \\
\text { R } \\
\text { Square }\end{array}$} & \multirow{2}{*}{$\begin{array}{c}\text { Std. } \\
\text { Error of } \\
\text { the } \\
\text { Estimate }\end{array}$} & \multicolumn{5}{|c|}{ Change Statistics } \\
\hline & & & & & $\begin{array}{c}\text { R } \\
\text { Square } \\
\text { Change }\end{array}$ & $\begin{array}{c}\text { FG } \\
\text { Change }\end{array}$ & df1 & $\mathrm{df} 2$ & $\begin{array}{c}\text { Sig. F } \\
\text { Change }\end{array}$ \\
\hline 1 & .913 & .834 & 1.88299 & .833 & 1.88299 & 105.82 & 1 & 160 & .000 \\
\hline
\end{tabular}

\section{Source: Researcher's Computation using the SPSS V.25.0}

The model summary result above show that the relationship between the predictors and dependent variables depicted by the regression coefficient $(\mathrm{R})$ value is $.913(91.3 \%)$. This means that there is a strong relationship between the two variables. Also, as indicated by the table, the variation is dependent variable as a result of the predicting variable, as indicated by $\mathrm{R}$ Square value, is $.834(83.4 \%)$. This implies that about $83.4 \%$ variations in employees' work efficiency (EWE) are explained by the work-life balancing (WLB) with the remaining $16.6 \%$ being accounted for by other factors not included in the model.

The F- Change is 105.829. This value is significant because the significant level is $=.000$ which is less than the 5\%. This suggest implicitly overall; regression model is statistically significant, valid and fit. This suggests implicitly that the independent variable explains that there is a positive and significant relationship between dependent and independent variables.

Table 2 Coefficients ${ }^{\mathrm{a}}$

\begin{tabular}{|c|c|c|c|c|c|}
\hline \multirow[t]{2}{*}{ Model } & \multicolumn{2}{|c|}{$\begin{array}{l}\text { Unstandardized } \\
\text { Coefficients }\end{array}$} & Standardized Coefficienats & \multirow[t]{2}{*}{$\mathrm{t}$} & \multirow[t]{2}{*}{ Sig. } \\
\hline & $\mathrm{B}$ & $\begin{array}{c}\text { Std. } \\
\text { Error }\end{array}$ & Beta & & \\
\hline $\begin{array}{l}\text { I(Constant } \\
\text { WLB }\end{array}$ & $\begin{array}{l}1.112 \\
.493\end{array}$ & $\begin{array}{l}.395 \\
.017\end{array}$ & .913 & $\begin{array}{c}2.819 \\
28.387\end{array}$ & $\begin{array}{l}.005 \\
.000\end{array}$ \\
\hline
\end{tabular}

a. Dependent Variable: EWE

\section{Source: Researcher's Computation using the SPSS V. 25.0}

The coefficients regression table above shows that physical Work-Life Balancing hashas .913 coefficient value with t-statistics value of 28.387 and Sig. value of .000 . This implication of this is that increase in Work-life Balancing by one percent, holding other variables constant, will lead to increase in Employees' Work Efficiency by $91.3 \%$. This result is significant in view of the Sig. value (of .000) which is far less than 5\%. Based on the empirical result revealed from the regression analysis, it is apparent that- there is significant influence of work-life balancing on employees' work efficiency in Ministry of Works and Infrastructure Bayelsa State- therefore, the above alternative hypothesis is accepted.

$\mathbf{H O}_{2}$ : There is no significant relationship between management/leadership style and employees' work-attitude in Ministry of Works and Infrastructure Bayelsa State. 


\section{Table 3 Model Summary}

\begin{tabular}{|c|c|c|c|c|c|c|c|c|c|}
\hline \multirow[t]{2}{*}{ Model } & \multirow[t]{2}{*}{$\mathrm{R}$} & \multirow{2}{*}{$\begin{array}{c}\mathrm{R} \\
\text { Square }\end{array}$} & \multirow{2}{*}{$\begin{array}{c}\text { Adjusted } \\
\text { R } \\
\text { Square }\end{array}$} & \multirow{2}{*}{$\begin{array}{l}\text { Std. } \\
\text { Error of } \\
\text { the } \\
\text { Estimate }\end{array}$} & \multicolumn{5}{|c|}{ Change Statistics } \\
\hline & & & & & $\begin{array}{c}\mathrm{R} \\
\text { Square } \\
\text { Change }\end{array}$ & $\begin{array}{c}\text { FG } \\
\text { Change }\end{array}$ & df1 & $\mathrm{df} 2$ & $\begin{array}{c}\text { Sig. F } \\
\text { Change }\end{array}$ \\
\hline & & & & & & & & & .000 \\
\hline 2 & $.863^{\mathrm{a}}$ & .769 & .769 & 2.01123 & .769 & 133.12 & 1 & 160 & \\
\hline
\end{tabular}

\section{Source: Researcher's Computation using the SPSS V. 25.0}

From the summary table above, the column of $\mathrm{R}$ is evidence that there is a correlation between the variables used in this study. The $\mathrm{R}=86.3 \%$. Its however, suggests that there is a relationship between management/leadership style and employees' work-attitude in Ministry of Works and Infrastructure Bayelsa State. On the other hand, the R-square is a measure of variance and how closely the variables are. With $13.7 \%$ rate, it therefore means that the explained the independent variable. However, from the table, the f value $\mathrm{f}$ (133.12) indicating that data obtained from the field survey do no support the null hypothesis, but that the data obtained from the field is compatible with the alternate hypothesis. However, the sig. value in the table is $\mathrm{p}=.000$ is lower than the $95 \%$ significance level that is 0.005 . Statistically, $(\mathrm{p}<\mathrm{a})$, this means that $.000<0.005$ significant. This therefore means that it is statistically significant.

Table 4Coefficients ${ }^{\mathrm{a}}$

\begin{tabular}{|c|l|c|c|c|c|}
\hline Model & \multicolumn{2}{|l|}{$\begin{array}{l}\text { Unstandardized } \\
\text { Coefficients }\end{array}$} & Standardized Coefficienats & \multirow{2}{*}{$\mathrm{t}$} & Sig. \\
\cline { 2 - 5 } & $\mathrm{B}$ & $\begin{array}{c}\text { Std. } \\
\text { Error }\end{array}$ & Beta & & \\
& & .379 & & 2.755 & .005 \\
2(Constant) & 1.247 & .029 & .831 & 19.417 & .000 \\
\hline
\end{tabular}

a. Dependent Variable: EWA

Source: Researcher's Computation using the SPSS V. 25.0

From the above regression and interpretation, we can therefore conclude that the management/leadership style has a significant effect on employees' work-attitude in Ministry of works and Infrastructure Bayelsa State. Thus, the null hypothesis is rejected.

\section{DISCUSSION OF FINDINGS}

This study found-out that work-life balancing has significant influence on employees work efficiency in Ministry of Works and Infrastructure Bayelsa State. This implies that (since multifaceted demand between heavy workloads and home responsibilities has taken dramatic increase especially in the recent times) conflict-free work-life gingers employees' activities and prevent them from embarking on wasteful exercise. This is because work-life balance (a flexible working and leave arrangement including dependent care assistance and general services) eradicate completely or reduce drastically, the likelihood of work-life conflict by ensuring that compatibility exists between work and non-work activities so as to ensure effective participation in both domains. Nowadays, work nature has changed from the usually 9-to-5 affair to a 24- hour and 7days because of fierce competition, market leadership challenge and customers' fastidious attitude. Thus, work-life imbalance drastically affects employees leading to deficient mental and physical health, occupational stress and lack of 
work satisfaction that result into inefficiency at work. From the employer's perspective, work-life imbalance consequences include poor job performance, high staff turnover, absenteeism, sigh recruitment and training costs.

\section{CONCLUSIONS}

Effective strategy can be used by many organizations to drive employees towards good performance through a hardly resistible remuneration packages. Work-life balance can be used to strongly influence employers work efficiency in Ministry of Works and Infrastructure Bayelsa State. Also, work-life balances (a flexible working and leave arrangements including dependent care assistance and general services) completely eradicate or drastically reduce, the likelihood of work-life conflict by ensuring that compatibility exist between work and non-work activities so as to ensure effective participation in both domains. Apparently, significance of supportive work-family structure, implicitly or explicitly, cannot be overemphasized because when employees' are happier with the relationship between their work role and family life; they become psychological attached to their organization, satisfied with their job and thus, perform efficiently.

Lastly, management/leadership style and employees' work-attitude in Ministry of Works and Infrastructure Bayelsa State. This implies that attitude of employees at work, positive or negative, is determined by the style of leadership puts in place.

\section{RECOMMENDATIONS}

The following recommendations are put forward:

i. There is an urgent need for the management of the Ministry of Works and Infrastructure Bayelsa State to ensure work-life balance by putting in place workconflict policies and programs that bolster employees' job role to ensure less stressrelated ill-health. The job structure should not be done in a way that each employee is not overstressed beyond his/her capacity. This is because when work-family structure is balance, implicitly or explicitly employees become happier with their work-role and family life, thus, they become more psychologically attached to their organization, satisfied with their job and thus, perform efficiently.

ii. Management of the Ministry of Works and Infrastructure in Bayelsa State should be careful of the leadership styles that they apply. Specifically, this study advocates for the use of situational leadership because this leadership style takes cognizance of the prevailing situation to determine its approach. Using situational leadership avails management, the opportunity to switch their style depending on employees' attitude. Management should take cognizance of the employee attitude when determining their style of leadership. Any leadership styles that areresisting by majority of employees should be discarded.

\section{REFERENCES}

1. Affum-Osei, E., \&Azunu, (2015). Relationship between occupational stress and demographic variables: A case study of employees in a commercial bank in Ghana. British Journal of Applied Sciences and Technology.

2. Assaf, A. M \&Alswalha, A. (2013). Environmental impacts of working conditions in paint factories workers in the Hashemite Kingdom of Jordan. European Scientific Journal, 9(8), 22-36

3. Duru, C. E. and Shimawua, D. (2017). The effect of work environment on employee productivity: A case study of edo city transport services benin city, edo state Nigeria. European Journal of Business and Innovation Research, 5(5), 23-39, 
4. Finminiyi, A.K. (2018). Impact of workplace environmental factors on employee commitment: evidence from north-east Nigeria. International Journal of Scientific Research and Management (IJSRM), 6(7), 575-588

5. Imam, A., \&Shafique, M (2014). Impact of employee engagement in retaining employees through mediating effect of job satisfaction and organizational commitment and moderating effect of job stress: A corporate banking sector study of Pakistan. Journal of Applied Environment and Biological. Sciences, 4(12)1-15

6. Ismail, J., Ladisma, M.,Mohd-Amin, S.H. \&Arapa, A. (2010). The influence of physical workplace environment on the productivity of civil servants: A case of the Ministry of Youth and Sports, Putrajaya, Malaysia. Voice of Academia, 5(1),71-78

7. Kunze, F., Boehm, S., \& Bruch, H. (2013). Organizational performance consequences of age diversity: inspecting the role of diversity-friendly hr policies and top manager's negative age stereotypes. Journal of Management Studies 50(3), 413-442

8. Mathews, C. \& Khan, I.K. (2015). Impact of work environment on performance of employees in manufacturing sector in India: Literature Review. International Journal of Science and Research (IJSR), 6(14):852-855

9. Miebi, U. (2014). Workforce diversity Management and corporate performance of firms in Nigeria. International Journal of Business and Management Review, 2(4), 36-46

10. Mmakwe, K.A. \&Ojiabo, U. (2018). Work-life balance and employee performance in Nigerian banks, port Harcourt. International Journal of Advanced Academic Research / Social \& Management Sciences, 4(1), 34-47

11. Nnamani, E. \&Ajagu, H.E. (2014). Environmental factors and organizational performance in Nigeria ( a study of Juhel Company). World Engineering \& Applied Sciences Journal, 5(3): 75-84

12. Rizwan, M., Nazar, K.., Nadeem, B., \&Abblas, Q. (2016). The impact of workforce diversity towards employee performance. American Journal of Marketing Research, 2(2) 53-60

13. Samson, Waignajo and Koima (2015). Effect of workplace environment on the performance of commercial banks employees in Nakuru town. International Journal of Managerial Studies and Research (IJMSR), 3(12):76-89 